\title{
COMMENT
}

\section{MUTUAL FUNDS AND INDEPENDENT DIRECTORS: CAN MOSES LEAD TO BETTER BUSINESS JUDGMENT?}

For mutual funds ${ }^{1}$ the 1960's were a time of enormous growth and high-flying performance, at least until the onslaught of a weak and

1. A mutual fund is a particular form of investment management company, namely, one that is "open-ended"--standing ready at all times to issue or redeem its shares at their net asset value. See Investment Company Act of 1940, § 5(a)(1), 15 U.S.C. $\S 80 a-5(a)(1)(1970)$. They are also almost always "diversified"-investing their assets in a portfolio made up of numerous different holdings. See id. $\S 5(\mathrm{~b})(1), 15$ U.S.C. $\S 80 \mathrm{a}-5(\mathrm{~b})(\mathrm{i})$. These distinctions, and some of their legal implications, are discussed at pages 39 through 45 of a report by the Securities and Exchange Commission, Public Policy Implications of Investment Company Growth, H.R. ReP. No. 2337, 89th Cong., 2d Sess. (I966) [hereinafter cited as PPI]. This Comment deals specifically with mutual funds, and while they have many aspects in common with other investment companies, much that is discussed herein is applicable only to mutual funds. At the end of 1970 mutual funds held assets of $\$ 47.6$ billion, or $95 \%$ of all investment company assets. INVESTMENT COMPANY INSTITUTE, 197I MUTUAL FUND FACT BOoK 7.

THE FOLLOWING HEREINAFTER CITATIONS ARE USED IN THIS COMMENT:

H.R. Rep. No. 1382, 91st Cong., 2d Sess. (1970) [hereinafter cited as House Report];

Practising Law Institute, Mutual Funds (1970) [hereinafter cited as PLI CONFERENCE];

Securities \& Exchange Commission, Public Policy Implications of Investment Company Growth, H.R. Rep. No. 2337, 89th Cong., 2d Sess. (1966) [hereinafter cited as PPI]:

Securities \& Exchange Commission, Statement on the Future Structure of the Securities MARKeTs, reprinted in 137 BNA SEC. REg. \& L. REP. pt. Il (1972) [hereinafter cited as Future Structure];

S. Rep. No. 184, 91 st Cong., ist Sess. (1969) [hereinafter cited as Senate Report];

Univ. of Pa. Law School Conference on Mutual Funds, 115 U. Pa. L. Rev. 659 (1967) [hereinafter cited as U. PA. CONFERENCE];

, Wharton School of Finance \& Commerce, A Study of Mutual Funds, reprinted in H.R. REP. No. 2274, 87th Cong., 2d Sess. (I962) [hereinafter cited as Wharton Report];

Eisenberg \& Lehr, An Aspect of the Emerging Federal Corporation Law: Directorial Responsibility Under the Investment Company Act of 1940, 20 RUTGERS L. REv. 181 (1966) [hereinafter cited as Eisenberg \& Lehr];

Eisenberg \& Phillips, Mutual Fund Litigation: New Frontiers for the Investment Company Act, 62 Colum. L. Rev. 73 (1962) [hereinafter cited as Eisenberg \& Phillips];

Glazer, A Study of Mutual Fund Complexes, 119 U. PA. L. Rev. 205 (1970) [hereinafter cited as Glazer];

Israels, A New Look at Corporate Directorship, 24 Bus. LAw. 727 (1969) [hereinafter cited as Israels];

Jaretzki, Duties and Responsibilities of Directors of Mutual Funds, 29 LaW \& CONTEMP. PRoB. 777 (1964) [hereinafter cited as Jaretzki]; 
uncertain stock market in the latter part of the decade. ${ }^{2}$ For mutual fund investor protection, however, it was a decade during which the limits of existing legal controls on mutual fund managers became apparent. The Investment Company Act of $1940,{ }^{3}$ its administrative and judicial implementation, and state-law fiduciary duties had virtually eliminated obviously dishonest and fraudulent practices by mutual fund managers. ${ }^{4}$ As was revealed by several special studies, however, there remained numerous mutual fund policies which seemed to serve the manager at the expense of investors. ${ }^{5}$ While such policies apparently were inconsistent with the declaration of section 1 of the Investment Company Act, that mutual funds should be run for the primary benefit of investors, ${ }^{6}$ during the 1960's mutual fund managers proved immune to existing legal attacks. This immunity was largely due to the defense that the policies resulted from honest business judgments, and as such were beyond both proscriptions against fraud and self-dealing, and the traditional standards of fiduciary duty. In such a context, Moses v. Burgin, ${ }^{7}$ an opinion dealing with circumstances which cannot recur, acquires significance beyond its facts. ${ }^{8}$

This Comment suggests that Moses imposes a new duty on mutual fund managers, and that in conjunction with certain of the 1970

Marsh, Are Directors Trustees?, 22 Bus. Law. 35 (1966) [hereinafter cited as Marsh];

Modesitt, The Mutual Fund-A Corporate Anomaly, 14 U.C.L.A.L. REv. 1252 (1967) [hereinafter cited as Modesitt];

Mundheim, Thoughts on the Duties and Responsibilities of Unaffiliated Directors of MH:tual Funds, 115 U. PA. L. Rev. 1058 (1967) [hereinafter cited as Mundheim].

2. See 1971 Mutual Fund Fact Book, supra note 1, at 10-11.

3. 54 Stat. 789 (1940), as amcnded, 15 U.S.C. $\$ 80 \mathrm{a}-1$ to -52 (1970).

4. PPI 1, 5. 71-72.

5. Id. 71-72. See notes 83-131 infra and accompanying text.

6. 15 U.S.C. $\$ 80 \mathrm{a}-1$ (b) $(1970)$.

7. 445 F.2d 369 (1st Cir.), cert. denied, 404 U.S. 994 (1971), rev'g 316 F. Supp. 31 (D. Mass. 1970).

8. Independent of the new duty ascribed to Moses in this Comment, the case is of topical significance and has been featured at a Federal Bar Association/Bureau of National Affairs Conference. 121 BNA SEC. REg. \& L. ReP. A-2 (1971). For example, while stock exchange rules changes have eliminated the procedure on which liability is based in Moses, see note 127 infra. more than fifty cases are pending on the same issue for activities prior to the rules change. In this respect the decision has been said to have "terrorized" the industry. The Bonb Thrower, Forbes, July 15, 1971, at 63 . The case has also sparked much discussion as to whether fund directors are under a duty to accomplish recapture of portfolio brokerage commissions by methods that are possible under existing exchange rules, see notes 105-22 infra and accompanying text, and suggests that brokerage commissions which are not recaptured, but which instead are used to purchase market research and sales effort, should be considered in judging whether an adviser meets the new $\S 36$ (b) fiduciary duty standards of compensation, see notcs $83-84$ 
amendments to the Investment Company Act ${ }^{9}$ it provides investors with some protection against mutual fund policies which serve the managers but are nonetheless legal. The new duty imposed under Moses should make the funds' independent directors ${ }^{10}$ more effective in their role as representatives of investor interests. Thus, as concern focuses on policies which neither violate existing law nor are readily subject to regulatory or judicial review, the courts and Congress are devising an approach which will facilitate greater protection from those who make business decisions in the name of the investors. ${ }^{11}$ This Comment will first survey the state of the mutual fund investor's protection at the end of the ' 60 's, particularly noting those practices which, although not proscribed by law, involve managerial conflicts of interest. There will then be a discussion of Moses v. Burgin. Finally, the Comment will explore the potential long-run significance of Moses, the questions it leaves open, and the problems and prömises of relying on independent directors to protect shareholders.

\section{Investor Protection-The Conventional ApProACH}

\section{The Mutual Fund Setting-A Challenge for Protection}

Mutual funds have long proven to be a pecular corporate entity in which "self-dealing is not the exception but, so far as management is concerned, the order of the day." 12 The typical fund is organized as a corporation or trust by a person who claims expertise in render-

infra and accompanying text. See generally Lipton, Rosenfeld v. Black, 4 REv. SEC. REG. 853 n. 23 (1971); 121 BNA SEC. REG. \& L. REP. A-2 (1971). In addition, a recent Note suggests that Moses demonstrates that there is a federal common law for mutual funds, and that the applicable fiduciary standards are relatively high. Note, Fiduciary Obligations of Mutual Fund Managers in Portfolio Transactions, 22 SYRACuSE L. REv. 1107, 1116, 1121 (1971).

9. Investment Company Amendments Act of 1970, 84 Stat. 1413 amending 54 Stat. 789 (1940) (codified at 15 U.S.C. $\$ \$ 80 a-1$ to -52 (1970)).

10. The Investment Company Act, 15 U.S.C. $\$ 80 \mathrm{a}-10(\mathrm{a}), 10(\mathrm{~b})(2)$ (1970), requires that at least $40 \%$ of the fund's board of directors be independent of its management, and that a majority be independent of its underwriter if any person connected with the fund has an intcrest in the underwriter. Since almost all underwriters are affiliates of the management, the practical effect of these sections is that a majority of a fund's board of directors is independent of the management.

11. There is irony in this argument that further advances in mutual fund investor protection will rely heavily on the funds' boards of directors-for the conventional impression of mutual fund dircctors is that they are hopelessly controlled by the management they must watch. See, e.g., PPI 130-31; U. PA. Conference 753 (comments of Abraham L. Pomerantz); Wharton REPORT 34; Mundheim 1058; note 177 infra. But see note 195 infra.

12. 445 F.2d at 376 . The unusual nature of mutual funds, and the resulting difficulties of effectively controlling their management, is discussed in Mundheim 1059-60. 
ing investment advice. ${ }^{13}$ The mutual fund itself is usually a hollow shell which hires an adviser to perform all operational and managerial duties, such as bookkeeping, custodial work, and the selection of portfolio securities. ${ }^{14}$ The fund has its own board of directors or trustees, of course, but these are usually chosen by and include the fund's organizer. ${ }^{15}$ Among the board's major responsibilities is official selection of both an investment adviser to direct the portfolio and an underwriter to oversee the distribution of the fund's shares. ${ }^{16}$ Not surprisingly, the organizing adviser receives the advisory contract and his affiliate receives the underwriting contract. ${ }^{17}$

Numerous conflicts of interest arise between the manager's role as fund director and his role as adviser under contract to the fund. Obviously, a conflict of interest exists as to the level of the fee to be paid by the fund for the adviser's services. In addition, the adviser has conflicts arising from such opportunities as those to select portfolio securities in which he has a personal position, ${ }^{18}$ to select a portfolio broker with whom he has financial ties, ${ }^{19}$ to "churn" ${ }^{120}$ the portfolio

13. PPI 46. Such persons are generally required to register under the provisions of the Investment Advisers Act of 1940, ch. 686, tit. II, 54 Stat. 847. However, those advisers whose only clients are investment companies are exempt under $\$ 203(b)(2)$ from this act's registration requirements and administrative sanctions. Such advisers are subject to control through the Investment Company Act.

14. PPI 45-47, 49-50; WhARTON REPORT 66. When dealing with mutual funds, one must remember that they are involved in two distinct aspects of the securities industry. On the one hand they issue their own shares to investors, through sales efforts by their own salesmen or more typically by salesmen obtained by the underwriter. On the other hand mutual funds use the assets obtained by the sale of their own shares to purchase investment securities issued by other corporations. These latter securities constitute the fund's "portfolio."

15. See note 177 infra.

16. The underwriter is essentially the wholesaler of the fund's shares. He makes arrangcments, typically with independent broker-dealers, for selling the fund's shares to the investing public, and supplies these shares as they are sold. Unlike the typical underwriter of other corporate securities, the mutual fund underwriter does not contract to raise a certain amount of capital for the issue; rather, he contracts only to purchase at net asset value those shares that have been sold to the public at net asset value plus the sales load. See text following note 92 infra.

17. PPI 54: Eisenberg \& Phillips 75-76.

18. For an example of such a practice in a similar situation, see SEC v. Capital Gains Research Bureau, Inc., 375 U.S. 180 (I963) (injunction granted compelling disclosure of the practice to an adviser's clients).

19. See notes 105-13, 130 infra and accompanying text for a discussion of indirect forms of such "kickbacks." Direct kickbacks to the adviser by an executing broker run afoul of section 17 of the 1940 Act, 15 U.S.C. \& 80a-17(e) (1970), that the adviser may receive no compensation for acting as the fund's agent, except as broker. See In re Imperial Financial Servs., SEC Securities Exchange Act Release No. 7684 (Aug. 26, 1965): In re Consumer Investor Planning Corp., id. No. 854. (Feb. 20, 1969): In re Hubshman Management Corp., id. No. 8557 (Mar. 20. 1969); In re Provident Management Corp., id. No. 9028 (Dec, 1. 1970). 
in order to create more brokerage commissions, and to sell selected appreciated securities in order to make showy but deceptive capital gains distributions. ${ }^{21}$ In general, the mutual fund setting is one of a highly liquid stock-in-trade, and of inherent conflicts of interest. ${ }^{22}$ The potential for abuse is subtle, often neither noticed nor understood by the unsophisticated investor. Further, it is not clear that the unaffiliated directors have fulfilled their statutorily prescribed role as watchdogs for the investor interest, for they have been largely controlled by the adviser ${ }^{23}$ and have often lacked the information needed to make independent judgments of fund policies. ${ }^{24}$ Given that the structure of mutual funds makes their investors peculiarly subject to management abuses, investors and the SEC have found it necessary to seek special legislative and judicial protection. ${ }^{25}$

\section{The Legislative Response}

The initial legislative effort to protect fund investors was through the Securities Act of $1933^{26}$ and Securities Exchange Act of 1934.27

One writer has expressed concern that section 17(e) may also reach indirect forms of kickbacks. See Butowsky, Mutual Fund Brokerage, 3 REv. SEC. REg. 915 (1970).

20. "Churning" is the practice of selling portfolio securities, but with the intention of repurchasing the same or similar securities shortly thereafter, in the absence of some sound investment reason for the transactions.

21. See notes 100-04 infra and accompanying text.

22. That the peculiarities of mutual fund structure lead to unusually heavy conflicts of interest is discussed at Mundheim 1059-61. However, the conflict is by no means total and there is a community of interest of the adviser and investor in some critical areas. For example, the adviser has a direct interest in good performance of the fund's portfolio because performance will affeet the fund's capacity to attract new investors, and thus the growth of the adviser's fee (which is usually a percentage of total assets). Glazer 207. Another trait of mutual fund structure is the "complex" of separate funds with common adviser, distributor, and often directors and officers. The manner in which this complicates issues of investor protection is the subject of the article by Glazer.

23. See notes 11 supra, and 177 infra.

24. Moses deals with this latter problem.

25. That their peculiar structure is the basis for special legislative controls of mutual funds is underlined in the legislative history of the 1970 amendments:

The relationship between the investment company and its investment adviser results in a structure which is different from the conventional bargaining relationship between buyer and seller. Since the typical mutual fund is organized by its investment adviser which provides it with almost all management services and because its shares are bought by investors who rely on those services, a mutual fund cannot, as a practical matter, sever its relationship with the adviser. Therefore, the forces of arm's-length bargaining do not work in the mutual fund industry in the same manner as they do in other sectors of the American economy. House RePORT 7.

26. 15 U.S.C. $77 \mathrm{a}$ to $77 \mathrm{aa}$ (1970).

27. Id. $78 \mathrm{a}$ to $78 \mathrm{hh}-1$. 
These acts basically imposed disclosure and antifraud provisions on corporations issuing securities and on the brokers and exchanges through which they were traded. This approach was effective in protecting investors of typical corporations, but it was inadequate to deal with the special problems of mutual funds.$^{28}$ Congress responded in 1940 with the Investment Company Act ${ }^{29}$ (hereinafter referred to as the 1940 Act) and Investment Adviser Act. ${ }^{30}$ While these acts expanded the disclosure approach, they also instituted a regulatory pattern involving both prescribed procedures and prohibited practices. Thus, for example, it was required that a portion of the fund's board be independent of the adviser, ${ }^{31}$ that advisory contracts be approved by investors and be renegotiated periodically, ${ }^{32}$ that no adviser or affiliate act as a principal in a transaction with the fund unless the SEC gave prior approval, ${ }^{33}$ and that no adviser or affiliate receive compensation as an agent of the fund, except for brokerage services actually rendered..$^{34}$ In addition, the 1940 Act specifically authorized action by the SEC against advisers who were guilty of "gross misconduct or gross abuse of trust" in their relations with the fund. ${ }^{35}$

The 1940 Act was largely successful in eliminating the blatantly dishonest abuses that had prompted its enactment. ${ }^{36}$ However, by the mid-1960's it was clear that more subtle problems existed, as detailed in the SEC's Report on the Public Policy Implications of Investment Company Growth (hereinafter referred to as PPI). ${ }^{37}$ Considerable concern was focused on the level of advisory fees, albeit they were approved by the independent directors, ${ }^{38}$ the effect of various sales

28. PPI 65. See generally SECURITIES \& EXCHANGE COMMISSION, REPORT ON INVESTMENT TRusts AND INVESTMENT Companies (1938-40). The House committee report on the 1940 Act states: "Generally [the 1933 and 1934] acts provide only for publicity. The record is clear that publicity alone is insufficient to eliminate malpractice in investment companies." H.R. REP. No. 2639, 76th Cong., 3d Sess. 10 (1940). See also Eisenberg \& Lehr 184-85.

29. Investment Company Act of 1940, ch. 686, tit. I, 54 Stat. 789.

30. Id. tit. II, 54 Stat. 847.

31. Id. tit. I, § 10a, 54 Stat. 806 (codified at 15 U.S.C. $\S 80 \mathrm{a}-10$ (a) (1970)). See note 10 supra.

32. Investment Company Act of I940, ch. 686, tit. I, $\$ 15(a), 54$ Stat. 812 (codified at 15

U.S.C. $\S 80 \mathrm{a}-15(\mathrm{a})(1970))$.

33. 15 U.S.C. $\$ 80 \mathrm{a}-17$ (1970).

34. Id. $\S 80 \mathrm{a}-17(\mathrm{e})$.

35. Investment Company Act of 1940 , ch. 686, tit. I, $\S 36,54$ Stat. 841 .

36. PPI 1, 5, 71-72.

37. See also Securities \& Exchange Commission, Report of the Special Study of Securities Markets, H.R. Doc. No. 95, 88th Cong., ist Sess. (1963); Wharton Report.

38. PPI 84-149. See note 75 infra and accompanying text. 
practices (in particular the "front-end load"), ${ }^{39}$ and the fact that the 1940 Act's requirement of "nonaffiliated" directors could be met, for example, with persons who were the sons of the adviser, or $4.9 \%$ owners of the advisory organization. ${ }^{40}$ The PPI proposed changes to the 1940 Act, and while Congress did not follow the SEC recommendations in full, the 1970 amendments do provide substantial new protections against some of the practices detailed in the PPI. The amendments impose a fiduciary standard on the level of advisory fees, ${ }^{41}$ place restrictions on the use of the front-end load, ${ }^{42}$ and loosen the requirements for SEC actions against advisers from gross abuse to "breach of fiduciary duty involving personal misconduct." 43 Of particular importance for the trend of investor protection with which this Comment deals, the 1970 amendments strengthen the requirement for qualification as nonaffiliated directors, making it one for "disinterested" directors and defining "interested person" to include family, business associates, and small stockholders of the adviser, the advisory organization, or affiliates of either.44

\section{The Judicial Response}

The judicial response to the problems of mutual fund investor protection has been keyed to the traditional common law duties of care and loyalty owed by corporate directors and insiders. While federal courts have been hesitant to directly apply these state-law standards ${ }^{45}$ they have nonetheless been incorporated in various ways into the securities acts. Thus "fraud" for the purposes of section 17a of the 1940 Act and rule 10b-5 $5^{46}$ promulgated under the 1934 Act has judicially been redefined so as to include violations of common law fiduciary duties. ${ }^{47}$ At least one federal case has held that the 1940 Act

39. PPI 201-50.

40. Id. at 332-35. See Acampora v. Birkland, 220 F. Supp. 527 (D. Colo. 1963); Coran v. Thorpe, 42 Del. Ch. 67, 203 A.2d 620 (1964); U. PA. CONFERENCE 738-40 (comments of Abraham L. Pomerantz).

41. 15 U.S.C. $\S 80 \mathrm{a}-35$ (b) (1970) (eff. June 14, 1972).

42. Id. $\$ 80 \mathrm{a}-27$ (d) to (h) (additions to 15 U.S.C. $\S 80 \mathrm{a}-27$ (1964)).

43. Id. § 80a-35(a) (1970), formerly ch. 686, tit. I, § 36, 54 Stat. 841 (1940).

44. Id. $\$ 80 \mathrm{a}-2(\mathrm{a})(19), 80 \mathrm{a}-10(\mathrm{a})$ (1970), formerly ch. 686, tit. I, $\$ 2(\mathrm{a}), 10(\mathrm{a}), 54$ Stat. 790,806 (1940).

45. See, e.g., 445 F.2d 369, 373, 376.

46. 17 C.F.R. $\S 240.10 b-5$ (1971).

47. Notc, Breach of Fiduciary Duty Involving Full Director Knowledge Held 10b-5 Violation, 1969 DUKE L.J. 383, 391-96. See, e.g., SEC v. Capital Gains Research Bureau, Inc., 375 U.S. 180 (1964); Schoenbaum v. Firstbrook, 405 F.2d 215 (2d Cir. 1968), cert. denied, 395 U.S. 906 (1969); Pappas v. Moss, 393 F.2d 865, $869-70$ (3d Cir. 1968): Entel v. Allen, 270 F. Supp. 60, $69-70$ (S.D.N.Y. 1967). 
incorporated the common law duties in toto. ${ }^{48}$ Other courts have found specific common law principles to be incorporated in particular sections of the 1940 Act. ${ }^{49}$ Further, both the federal courts and the SEC have liberally construed the "gross abuse of trust" provisions of the original section 36,50 and the federal courts have ruled that violations of the Act, including section 36 , create causes of action in private shareholders. ${ }^{51}$ In any case, now that section 36(a) of the Investment Company Act establishes the standard of "breach of fiduciary duty involving personal misconduct," ${ }^{52}$ the federal courts should have little difficulty in applying common law standards. ${ }^{53}$ It is significant to note that the federal courts have limited themselves, in the absence of statutory prohibitions of specific practices, to protecting against conduct which is reached by the traditional state-law fiduciary duties of care and loyalty. The balance of this piece will thus discuss the limits on the reach of the traditional duties, and the way

48. Aldred Inv. Trust v. SEC, 151 F.2d 254, 260 (2d Cir.), cert. denied, 326 U.S. 795 (1945). See also Rosenfeld v. Black, 445 F.2d 1337, 1342, 1344-45 (2d Cir. 1971); Brown v. Bullock, 194 F. Supp. 207, 234 (1961).

49. Of particular significance is the recent case of Rosenfeld v. Black, 445 F.2d 1337 (2d Cir. 1971), petition for cert. filed sub nom. Lazard Freres \& Co. v. Rosenfeld, 40 U.S.L.W. 3289 (U.S. Dec. 10, 1971) (No. 71-771), in which the equitable principle that a fiduciary may not profit from the sale of his office was found to be implicit in $\S 15(\mathrm{a})$. Id. at 1345. This case has been noted in Comment, An Investment Adviser May Not be Compensated for Influencing Stockholder Approval of a New Adviser, 46 N.Y.U.L. REv. 1029 (1971); Note, Fiduciary Requirements and the Succession Fee Upon the Change of Mutual Fund Advisers, 85 Harv. L. REv. 655 (1972); 40 GEO. WASH. L. Rev. 312 (1971).

50. See, e.g., Aldred Inv. Trust v. SEC, 151 F.2d 254, 260 (2d Cir.), cert. denied, 326 U.S. 795 (1945) (violation of duty of loyalty, incorporated by section 1, see note 44 supra and accompanying text, held gross abuse of trust); Brown v. Bullock, 194 F. Supp. 207, 238-39 (S.D.N.Y.), affd under other sections, 294 F.2d 415 (2d Cir. 1961) (that section 36 constitutes a residual provision imposing duties not specifically included in other provisions). See generally Eisenberg \& Lehr, discussing these cases, as well as several that are more restrictive, and arguing for an expansive approach to seetion 36. A more recent example of the flexibility of "gross abuse of trust" is contained in Moses v. Burgin, where essentially it was interprcted to reach all practices which Congress implicitly forbade when it passed the 1940 Act. $445 \mathrm{~F} .2 \mathrm{~d}$ at 384.

51. See, e.g., 445 F.2d at 373; Esplin v. Hirschi, 402 F.2d 94, 103 (10th Cir.), cert. denied, 394 U.S. 928 (1968); Tanzer v. Huffines, 314 F. Supp. 189, 193 (D. Del. 1970); Brown v. Bullock, 194 F. Supp. 207, 245 (S.D.N.Y. 1961); contra, Brouk v. Managed Funds, Inc., 286 F.2d 901 (8th Cir. 1961), dismissed, 369 U.S. 424 (1962), with which compare Greater lowa Corp. v. McLendon, 378 F.2d 783, 789-90 (8th Cir. 1967). For an early discussion, when the point was in doubt, see Eisenberg \& Phillips 84-101.

52. 15 U.S.C. $\$ 80 \mathrm{a}-35$ (a) (1970), formerly ch. 686, tit. I, § 36, 54 Stat. 841 (1940).

53. The effect of the phrase "involving personal misconduct" is not apparent in the amendment or its legislative history. The House and Senate reports state that it may extend to nonfeasance or abdication of responsibility, and is not to be limited to cases of intentional violations. House REPORT 37; SeNATE REPORT 36. 
in which Moses may contribute to more effective investor protection against mutual fund policies which do not violate these standards.

The duty of care. The duty of care is applicable to directors with regard to matters in which they have no personal interest, as opposed to the duty of loyalty which comes into play where a director or officer has a personal financial interest in the outcome of a corporate decision. Thus in the mutual fund setting in which the affiliated directors are frequently exposed to conflicts of interest, the duty of care is usually relevant only to the independent directors. ${ }^{54}$ The duty requires that directors pay attention to their corporation's policies and affairs, and that they not negligently ignore its activities. ${ }^{55}$ Basically the directors are required to do the job of directing for which they have been retained. The authorities indicate that the plaintiff carries the burden of proving damage from breach of this duty, ${ }^{56}$ and that the director may defend by showing that he was not negligently unaware of a challenged transaction ${ }^{57}$ or that he made an honest business decision with regard to it. ${ }^{58}$ Thus circumscribed, the duty of care is of little use to investors seeking protection against the more subtle methods by which managers can take advantage of their funds. Such duty has been the basis for liability in relatively few cases, ${ }^{59}$ and only one of these, Lutz v. Boas, ${ }^{60}$ involved a mutual fund. The Lutz litigation concerned an adviser's receipt of a substantial fee for which he did almost nothing, having farmed out virtually all responsibility for portfolio selection to a broker/adviser who was paid by being

54. Of course the directors who are affiliated with the adviser must also conform to the standards imposed by the duty of care. However, these are usually not the operative standards facing an affiliated director because his conflicts of interest make him subject in most instances to the stiffer standards of the duty of loyalty.

55. Israels 729-32; Jaretzki 779-80. See, e.g., Neese v. Brown, 218 Tenn. 686, 405 S.W.2d 577 (1964).

56. See, e.g., Barnes v. Andrews, 298 F. 614 (S.D.N.Y. 1924); H. Ballantine, CorporaTIONS $\S 63 \mathrm{~b}$ (1946); Note, The Nonratification Rule and the Demand Requirement, 63 Colum. L. Rev. 1086, 1100 (1963).

57. Jaretzki 779. This defense includes the right to rely on information supplied by, e.g., auditors or management. Israels 731. For an indication of its limits, see Heit v. Bixby, $276 \mathrm{~F}$. Supp. 217 (E.D. Mo. 1967) (directors held liable for having negligently failed to discover an arrangement whereby other officers and directors reccived a secret commission on a management fee paid by the corporation); Barnes v. Andrews, 298 F. 614 (S.D.N.Y. 1924) (L. Hand, J.) (directors liable for negligent failure to keep himseif informed of operational deficiencies).

58. H. Ballantine, supra note $56, \S 63 \mathrm{a}$; M. Feuer, Personal Liabilities of CorpoRATE OFFICERS AND DIRECTORS 20-22 (1961); Israels 731.

59. Bishop, Sitting Ducks and Decoy Ducks: New Trends in the Indemnification of Corporate Directors and Officers, 77 YALE L.J. 1078, 1095-99 (1968); Israels 730.

60. 39 Del. Ch. 585, 171 A.2d 381 (1961). 
assigned all of the fund's brokerage business. In addition to holding the adviser and the broker liable, the court imposed joint liability on the independent directors for breach of their duty of care-while they had gained nothing from the arrangement, they were grossly negligent in allowing it, had failed to inquire into how the fund was operated, and had generally abdicated responsibility to the adviser. ${ }^{01}$ However, while the duty of care as applied in Lutz may serve as a useful reminder that one must not be a director in name only, it hardly provides protection against abuses that are not already adequately dealt with by either securities legislation or the more stringent duty of loyalty. ${ }^{62}$

The duty of loyalty. This duty, as developed in the context of the normal business corporation, is invoked where a corporate decisionmaker has a personal interest which might affect the singlemindedness with which he seeks to serve his shareholders. Embodying the basic principle that a fiduciary may serve only his cestuis, not himself, it is much more stringent than the duty of care, but its precise nature varies in each of four basic situations. ${ }^{63}$ In the case of transactions between a corporation and a director (or another corporation in which the director has an interest), early courts deemed such transactions to be void, regardless of their basic fairness. ${ }^{64}$ This rule has been softened, and now a test of fairness is usually applied, especially if the transaction was approved by disinterested members of the board. ${ }^{65}$ Where such board approval is obtained the plaintiff bears at least the burden of coming forward with evidence of unfairness, ${ }^{66}$ and in a majority of states he would also have the burden of proof. ${ }^{67}$ The

61. Id. at 608-10, $171 \mathrm{~A} .2 \mathrm{~d}$ at $395-96$.

62. "The duty of care affords only cursory control of directors activities." Glazer $211 \mathrm{n}$. 45. See also Acampora v. Birkland, 220 F. Supp. 527 (D. Colo. 1963), in which nonaffiliated directors allowed the fund to pay various expenses which under the advisory contract should have been paid by management. While management was required to refund these amounts, the nonaffiliated directors were judged against the standard of gross negligence and not held liable. Id. at 550 .

63. More elaborate classification schemes are possible. See, e.g., M. FEUER, supra note 58 , at 31-32; Eisenberg \& Lehr 226; Marsh 58-72.

64. Marsh 36-39.

65. See Schlensky v. South Parkway Bldg. Corp., 19 III. 2d 268, 166 N.E.2d 793 (1960): Eisenberg \& Lehr 262; Israels 733-34; Marsh 43-44. See also Model Bus. Corp. Act ANN. 2D If 41 (Am. Bar Foundation 1971) (valid if approved by disinterested director or shareholder, or if "fair and reasonable to the corporation").

66. Eisenberg \& Lehr 222, 263.

67. Eisenberg \& Lehr 263. This frequently results from corporate charter provisions, or perhaps by statute. See generally Israels 734-35; Marsh 45; 63 CoLUM. L. REv., supra note 56, at ll01. But see W. Cary, Cases and Materials on Corporations 566 (1969). This 
standard as just stated has been applied primarily in cases where a direetor buys from or sells to the corporation, ${ }^{68}$ a somewhat greater burden is on the managers where they cause the corporation to buy its own shares in order to fend off a challenge to their control, ${ }^{69}$ and a virtual prohibition is imposed on seizure of a corporate opportunity by an officer or director, except that the opportunity may be available to the insider if the corporate board has legitimately abandoned it. ${ }^{70}$ Finally, there are less obvious situations where the director is not directly involved in the proposed transaction, but where he does stand to gain if a certain decision is made-for example, where he has a personal holding in stock which the fund is considering for its portfolio. In these latter cases the emphasis is on disclosure of the interest to the independent directors. ${ }^{11}$

Since conflicts of interest are endemic to the mutual fund structure ${ }^{72}$ one would expect the duty of loyalty to be of considerable significance to investor protection. However, in few cases has it been the basis for liability, primarily due to preemption by the 1940 Act. Section $17^{73}$ of that legislation prohibits an adviser from acting as a principal in transactions with the fund, and from acting as its agent in a capacity other than that of broker, except with prior SEC approval. ${ }^{74}$ This fails to explain, however, why the adviser's fee, which is not controlled by section 17 , is not subject to a test of fairness under the duty of loyalty. The test actually applied, as indicated by four cases that have reached the question, ${ }^{75}$ is excessiveness to the point of spoliation or waste. By applying this standard, the courts have rejeeted the test that has traditionally been appropriate for transactions between a director and his corporation. The waste standard, on

contrasts with the historic rule that the burden is on those seeking to sustain a transaction with a director. See, e.g., Geddes v. Anaconda Copper Mining Co., 254 U.S. 590, 598 (1921); Shlensky v. South Parkway Bldg. Corp., 19 Ill. 2d 268, 166 N.E.2d 793 (1960). The burden may also be shifted to the challenger by shareholder ratification of the transaction. See 63 CoLUM. L. Rev., supra at 1101-02.

68. The somewhat different rules applied to a related issue, that of the excessiveness of a corporate insider's compensation, are discussed in notes 75-76 infra and accompanying text.

69. See Eisenberg \& Lehr 247-52, 263-64. See also Marsh 60-63.

70. See Guth v. Loft, Inc., 23 Del. Ch. 255, 5 A.2d 503 (Sup. Ct. 1939); Eisenberg \& Lehr 252-62, 264; Wadmond, Seizure of Corporate Opportunity, 17 Bus. Law. 63 (1961).

71. Wadmond, Conflicts of Business Interests, 17 Bus. Law. 48, 62 (1961).

72. See notes 12-22 supra and accompanying text.

73. Investment Company Act of 1940 , 15 U.S.C. $\S 80 \mathrm{a}-17$ (1970).

74. Marsh 73.

75. Acampora v. Birkland, 220 F. Supp. 527 (D. Colo. 1963); Saxe v. Brady, 40 Del. Ch. 474, 184 A.2d 602 (1962); Saminsky v. Abbott, 40 Del. Ch. 528, 185 A.2d 765 (1961); Meiselman v. Eberstadt, 39 Del. Ch. 563, 170 A.2d 720 (1961). 
the other hand, has traditionally been used to determine whether an insider receives excessive compensation for his services as director or corporate officer, ${ }^{76}$ and depends heavily on stockholder and independent director approval of the transaction's terms. ${ }^{77}$ Its effect is to place the level of advisory fees almost beyond attack. For example, in Acampora $v$. Birkland,$^{78}$ the court agreed that the fee, which was higher than the industry average, was determined on a questionable basis in that it failed to make allowances for economies of scale as the fund grew. However, the court could not find the "shocking" or "unconscionable" excessiveness required by the landmark case on the subject, ${ }^{79}$ Saxe v. Brady. ${ }^{80}$

Treatment of transactions between the fund and its adviser seems to be inconsistent. On the one hand, section 17 of the 1940 Act prohibits most transactions in which the adviscr acts as a principal, such as sale to the fund of stocks owned by the adviser, and even if permissible under federal law, these transactions would be subject to the common law test of fairness. On the other hand, the contract which determines the adviser's direct compcnsation is virtually beyond challenge. Two reasons for this difference are suggested. First, the advisory contract is out in the open and rcceives stockholder approval, albeit few investors may understand its implications for excessiveness. Second, the advisory contract seems to fall within the area in which directors must necessarily exercise their discretion, and as such, receives the loose treatment given honest business judgments. While it is quite necessary that a board negotiate some arrangement for investment advice, it is clearly not necessary that it buy portfolio

76. Modesitt 1263. For a discussion of the general rulc, see Eisenberg \& Lehr 238-47.

77. Rogers v. Hill, 289 U.S. 582, 591-92 (1933) (the classic corporate excess compensation case); Saxe v. Brady, 40 Del. Ch. 474, 486, 184 A.2d 602, 610 (1962); Meiselman v. Eberstadt, 39 Del. Ch. 563, 568, 170 A.2d 720, 723 (1961).

There is reason to doubt that substantial weight should be accorded these factors in the advisory fee context. First, the independent directors are likely to be heavily influenced by the management, see notes 11 supra and 177 infra. Second, compensation expressed in terms of a percentage of total assets gives the typical shareholder no indication of the profit and personal incomes of the adviser and his staff; this contrasts sharply with dollar-amount information that is available concerning the personal compensation of executive officers of normal corporations.

For the argument that ratification should have no effect on shifting the applicable standard in federal courts under the $1940 \mathrm{Act}$, inasmuch as section 36 makes no provision that it should, see Eisenberg \& Lehr 225. The 1970 amendments provide that ratification shall be given such consideration "as is deemed appropriate under all the circumstances." 15 U.S.C. $\$ 80$ a35(b)(2) (1970). See notes 73-74 supra and accompanying text.

78. 220 F. Supp. 527 (D. Colo. 1963).

79. Id. at 548-49.

80. 40 Del. Ch. 474,184 A.2d 602 (1962). 
securities from the adviser. The advisory contract, being a normal exercise of directorial discretion, apparently does not invoke the suspicion that is accorded other forms of dealing between insiders and the corporation. ${ }^{81}$ Thus, at the point where dealing with an insider merges into the normal exercise of directorial power, the courts have opted to apply the standard appropriate to the latter ${ }^{82}$-despite the unusually heavy influence over the entire board normally possessed by the mutual fund adviser.

\section{Permissible Policies Serving the Adviser}

It should be readily apparent from the foregoing survey of mutual fund investor protection that an array of conflicts exists between the interests of investors and of the adviser, and that with regard to many of these the decision of the mutual fund board is final. These are areas which are not substantively regulated by the securities acts and which fall within the normal discretion of the board of directors, at least where the independent directors are aware of the conflicts. An exploration of five of these areas follows.

The adviser's compensation. The obvious example is compensation under the advisory contract, as just discussed. Of course it may be that for federal courts the 1970 amendment, subjecting advisory compensation to a fiduciary standard, ${ }^{83}$ has changed the test from waste to fairness-certainly such a result was intended by the SEC in its original proposal of a "reasonableness" standard ${ }^{84}$ However, even if the courts do liberally interpret the new language, the statute provides that the burden of proof rests on the plaintiff. ${ }^{85}$ In any event considerable scope remains within which a board of directors, heavily

81. This permissive treatment is quite consistent with the rule protecting disinterested directors in their exercises of business judgment. See notes 54-62 supra and accompanying text.

82. See Modesitt 1263.

83. 15 U.S.C. \$ 80a-35(b) (1970).

84. PPI 143-44. For a criticism of the proposal to tighten the standard from waste to reasonableness, see Modesitt 1266-70. Whether the amendment will have this effect has not yet been clearly determined, and was a point of conflict between the SEC and the Investment Company Institute during the passage of the Act. Compare Hearings on H.R. 11995, S. 2224. H.R. 13754 \& 14737 Before the Subcomm. on Commerce \& Finance of the House Comm. on Interstate and Foreign Conmerce, 91 st Cong., Ist Sess., pt. 1, at 187, 199-203 (1969) (SEC's interpretation) with id. 44I (ICl's interpretation). For recent conficting views on this issue, see Baris, Mutual Fund Legislation, 4 Rev. SeC. REg. 977, 978-80 (1971) and Freedman \& Rosenblatt, Duties to Mutual Funds, id. at 937, 939-40. See also PLI CONFERENCE 306-11.

Two other writers state: "The 1970 Mutual Fund Act . . . creates an enforceable standard of reasonableness with respect to management fees." Miller \& Carlson, Recapture of Brokerage Commissions by Mutual Funds, 46 N.Y.U.L. REv. 35, 69 (1971).

85. 15 U.S.C. $\S 80 \mathrm{a}-35(\mathrm{~b})(1)(1970)$. 
influenced by the adviser, can accord him more compensation than would be necessary in order to obtain his services through arm'slength bargaining.

Mutual fund growth. Another issue whose resolution under prevailing law is clearly immune from investor attack, but which involves conflicts between the interests of investors and the adviser, is that of the optimum size of a mutual fund. ${ }^{86} \mathrm{Up}$ to a point it is to the investor's advantage for the fund to grow, at least if some of the economies of scale are passed along to them through lower advisory fees. ${ }^{87}$ However, as has become clearer in the difficult market conditions since 1968, the very large fund has problems with execution of its portfolio transactions. ${ }^{88}$ The difficulty is that large blocks cannot easily be assembled or sold by the fund without upsetting the market, so that large funds tend to be unable to obtain as good a net price in as short a period of time. This poorer "execution" not only hampers performance on a security which is purchased, but also reduces the flexibility with which an adviser can choose portfolio securities. Thus the interest of investors possibly lies in a fund's limiting its growth once it reaches the size where it encounters significant execution difficulties. ${ }^{89}$ On the other hand, the interest of the adviser is clearly against any such limitation, for his fee grows with the fund's total assets. ${ }^{90}$ Despite the presence of this conflict, however, existing law

86. See generally PPI 251-63.

87. See note 90 infra. For the proposition that there are economies of scale, see Glick, Mutual Fund Management Fees: In Search of a Standard, 25 Bus. LAw. 1471, 1475-76 (1970); WhARTON REPORT 492, 503.

88. See A Tougher Game, ForBes, Aug. 15, 1971, at 72, 74; PPI 263; Glazer 254.

89. According to Glazer, the portfolio manager of one well-known fund has requested that sales be closed to new shareholders when the fund reaches $\$ 500$ million, on grounds that he could not do as good a job on a larger portfolio. Glazer 254 n.228.

This point is hotly contested, however, and there are countervailing business considerations. The argument most frequently pressed is that a substantial net cash inflow eliminates forced sales of securities to meet demands for redemption and to take timcly advantage of new investment opportunities. On the other hand, Forbes reports that "fundmen" now claim that new redemptions do not hurt performance, basing this on SEC figures and performance comparisons of mutual funds and "closed-end" investment companies (in which no redemptions are possible). The Redeemers, Forbes, June 15, 1971, at 70-71. The various conisiderations, pro and con, are discussed at Glazer 253-55. See also PLI CONFERENCE 145-48.

90. Industry practice is to set the adviser's fee as a percentage of the fund's assets. This fee was once typically one-half of one percent regardless of the size of the fund. However, a decreasing figure for assets over a given amount, say $\$ 100$ million, has become popular since the WHARTON REPORT at $489-91$ pointed out that the flat percentage fee failed to pass along to the investors the considerable economies of scale associated with mutual fund growth. See PPI 89, 100-01, 110 .

The trend towards a sliding fee has also been given some impetus by dieta questioning the flat fee, Acampora v. Birkland, 220 F. Supp. 527, 548-49 (D. Colo. 1963); Saxe v. Brady, 40 Del. Ch. 474, 498, 184 A.2d 602, 616-17 (1962). 
provides no assurances that the issue will be resolved with an eye to the investor's interest. The decision is well within the scope of the business judgment rule, and to challenge it would involve severe difficulties of proof. Further, while the SEC recognizes the problem, it has not yet found it to be so serious as to propose a legislative resolution..$^{91}$

The sales load. The level of the sales load is another area in which investors and advisers have different interests. ${ }^{92}$ The sales load is a percentage of a share's value added to its price when sold to the investor and is used to compensate both the underwriter who distributes the shares and, more importantly, the salesman who convinces the investor to buy them. That the sales load level is important to the growth of a fund is suggested by the slogan "mutual funds are sold, not bought." Without a substantial sales load there will be insufficient incentive for the salesmen to expend the effort needed to attract investors. Thus the adviser, whose income goes up as the fund grows, is best served by a heavy sales load.$^{93}$ On the other hand, the investor's interest is best served through maximization of his effective return by paying the smallest amount possible for each share of given value and growth potential. Of course the prospective investor is informed of the sales load, and it is difficult to claim that the manager or directors have any duties to an investor before he has freely chosen to invest in the fund. However, much mutual fund investing is effected by persons who already hold shares, ${ }^{94}$ and it is clear that directors representing their interests should seek to reduce the cost of further investments, at least so far as is consistent with the legitimate need of the fund to maintain steady sales..$^{95}$ Nonetheless, because of the voluntary nature of paying the sales load, and the element of business judgment as to the desirability of further growth, the common law seems to impose no duty to lower the load regardless of how high it might be. The only protection of any effect is the competition of other funds willing to undercut an exorbitant sales load. ${ }^{96}$ As a result, in

\footnotetext{
91. PPI 263.

92. See generally id. at 204-23. As of 1966 there were about 60 mutual funds that imposed no sales loads. However, they accounted for only about $5 \%$ of total mutual fund assets. Id. at 52.

93. See id. at 208-09 for a discussion of the tendency of the competition for sales effort to cause increases in both the sales load and the portion of it paid to the selling dealer.

94. Mundheim 1069.

95. See note 89 supra.

96. Cf. U. PA. Conference 804 (comments of Herbert R. Anderson); Modesitt 1270. For a discussion of the inadequacy of various relevant statutory provisions, such as approval by the unaffiliated directors, see PPI 217-26.
} 
its Public Policy Implications Report the SEC proposed a five percent maximum. ${ }^{97}$ Congress responded by providing for control by the industry itself, ${ }^{98}$ but as yet no regulations have been issued.$^{98}$

Capital gains distributions. Another common practice which apparently contributes to the saleability of fund shares is that of distributing realized long-term capital gains to the investors, rather than reinvesting them in the fund. ${ }^{100}$ That high steady "dividends" increase the sales appeal of mutual fund shares is reflected by those funds which go so far as to liquidate appreciated portfolio securities solely to realize a distributable capital gain. ${ }^{101}$ Taken to this extreme, the policy has the harmful results typically associated with churning of the portfolio-unnecessary brokerage commissions, sacrifice of longterm growth potential of those securities which are sold, and immediate recognition of taxable capital gains. Even if the practice of regular distributions does not dominate portfolio policies, it does mislead the many investors who fail to understand that the distribution is from the corpus of their investment rather than its income. ${ }^{102}$ Current legal protections for the investor's interest are the requirement that a mutual fund's prospectus accurately state its investment policies ${ }^{103}$ and the SEC's newly-enacted power to prohibit capital gains distributions more than once a year. ${ }^{104}$ Otherwise, neither legislation nor the tradi-

97. PPI 223.

98. 15 U.S.C. \& 80a-22(b) (1970).

99. Under section 22(b) NASD has until June 14, 1972 before the SEC assumes its role of overseer of the regulations. A study of the problem by an independent consulting firm was to be presented to NASD in the spring of 1972. 144 BNA SEC. REG. \& L. REP. A-1 to -3.

100. PPI 190-95.

101. For a rccent account of the capital gains distribution practices of one fund, suggesting realization and distribution of selected capital gains in order to maintain shareholder confidence, see Making It. Forbes, May I, 1971; at 64.

102. Jaretzki 791-92. It should be noted that important tax advantagcs result from distributions of ordinary income. INT. REv. CODE of 1954, $\S 852$ (a)(1); PPI 41. These advantages do not attach to distributions of capital gains. INT. REv. CODE OF 1954, § 852(b)(3); PPI 190 91.

In 1970, mutual funds distributed $\$ 1.4$ billion as income dividends and $\$ 0.9$ billion as capital gains. For 1969 these figures were \$1.2 billion and \$2.5 billion respectively. 1971 MUTUAL FUND FACT Book, supra note 1, at 17.

103. See Managed Funds, Inc., 39 S.E.C. 313, 321-23 (1959), in which a Commission stop order, suspending the cffectiveness of the fund's registration statemcnt, was premised, inter alia, on the finding that the prospectus stated the fund's objective to be capital growth, whereas its de facto primary objective was to provide a high and uniform rate of cash flow.

104. Investment Company Amendments Act of 1970, \& 11, 15 U.S.C. \$ 80a-19(b) (1970). The SEC proposed such a rule in Investment Co. Act Rclease No. 6735 (Oct. 1, 1971). The purpose of this provision is to minimize shareholder confusion of "dividends" derived from income and those derived from capital gains. 
tional duties of insiders suggest that fund managers should sacrifice the sales appeal of high distributions.

Use of brokerage commissions. One last area in which apparently lawful policies of many mutual funds are of obvious service to the adviser's interest, at the probable expense of the investor, is the use of the enormous brokerage commissions paid by mutual funds on purchases and sales of their portfolio securities. ${ }^{105}$ It was from this area of conflicting interests that Moses v. Burgin arose. The particular value of brokerage results from stock exchange rules which for most transactions set a minimum percentage brokerage fee based on the total amount of the purchase or sale. The broker's cost for effecting a transaction does not increase proportionately with its size, but the applicable minimum fee percentage does not decline by an offsetting amount. This combination means that the larger transactions are economic plums to a broker. ${ }^{106}$ So valuable are these larger transactions that brokers are willing to perform various services in addition to brokerage if the mutual fund directs such business to it. Thus a few funds obtain their advisory services at no extra charge from the broker who handles their portfolio transactions. ${ }^{107}$ More frequently, mutual funds advisers obtain market research and information from brokers whom they "pay" with the fund's brokerage business. ${ }^{108}$

The outright cash value of brokerage was most apparent in the "customer-directed give-up," 109 a practice uniformly engaged in by mutual funds and brokerage houses until its abolition in 1968."10 While the stock exchange rules prohibit a direct kickback of part of the brokerage fee, ${ }^{111}$ the rules were liberally interpreted to allow the customer to direct his broker to pay a portion of the commission to another member of the exchange, or in some cases to any securities dealer. ${ }^{112}$ Under the fee schedule then in effect, these give-ups would

105. See generally PPI 155-88. For the year ended June 30, 1966, brokerage commissions paid by mutual funds totaled about $\$ 100$ million. See id. at 165-66.

106. See 445 F.2d at 372; PPI 163.

107. Glazer 248. See, e.g., Lutz v. Boas, 39 Del. Ch. 585, 171 A.2d 381 (1961) (summarized in the text accompanying note 61 supra).

108. PPI 163-64.

109. See generally id. at I69-72; Note, The Use of Brokerage Commissions to Promote Mutual Fund Sales: Time to Give Up the "Give-Up," 68 CoLum. L. Rev. 334 (1968).

110. N.Y. STOCK EXChange Const. art. XV, \& 8, reprinted in 2 CCH N.Y. STOCK Exchange Guide $\S 1708$.

III. Id. $\S \mathrm{I}, \uparrow 170 \mathrm{I}$.

112. While not allowed by the New York and American Stock Exchanges, six of the seven regional exchanges permitted all members of NASD to receive give-ups, without regard to regular exchange membership. PPI 17 I. 
typically amount to 40 percent of the commission and not uncommonly would reach 60 percent or even 70 percent. ${ }^{113}$

That portion of the minimum brokerage fees in excess of what the executing broker requires represents an enormous amount of economic power that can be directed with considerable flexibility within the securities business. Normally the mutual fund management uses the brokerage commissions to obtain three services-sales effort, market information, and investment research. ${ }^{114}$ In many cases the bulk of the brokerage is used to reward dealers who sell the fund's shares. ${ }^{115}$ The normal arrangement is for the manager to direct to a selling organization brokerage having a cash value of one to five percent of the organization's sales of fund shares, ${ }^{116}$ this being in addition to the seller's commission of about six percent derived from the sales load. ${ }^{117}$ The critical nature of this additional compensation is underlined by the importance, mentioned above, ${ }^{118}$ of selling mutual fund shares rather than merely offering them to be purchased, and by the fact that most mutual funds are absolutely dependent for sales effort on broker/dealers who can, if the pay is better, push someone else's fund. ${ }^{119}$

In the light of the earlier discussions of divergence between the interests of fund managers and their investors, the conflict in this case should be obvious-the manager has a tremendous interest in using the brokerage to generate sales, in order to increase the size of the fund and thus increase his advisory fee, while the investor's interest

113. Id. at 170 .

114. Id. at 163-67.

115. As of 1966 , the 20 largest funds without affiliated brokers allocated $53 \%$ of their brokerage commissions to pay for sales efforts. $I d$. at 165-66. However, this practice may soon be terminated, due to recent SEC action. See note 128 infra.

At this point it might be useful to emphasize a distinction mentioned earlier-that between the fund's activities as an issuer of its own shares, and as a purchaser and seller of shares issued by other corporations. It is for selling the shares issued by the fund itself that advisers seek to reward salesmen, and it is the success with which these shares are sold that determines the fund's total assets and thus the adviser's fee. On the other hand, it is the fund's activities as a purchaser and seller of other securities, for its investment portfolio, that generates brokerage commissions-which are compensation for the broker's professional services of arranging and effecting the transaction. It is from these commissions the give-ups are derived. That the same organization can be involved with the mutual fund in both of these activities, as selling dealer and as broker, complicates matters but also makes it possible to reward directly that broker-dealer for its sales success by allowing it to perform brokerage services.

116. SPECial Study of Securities Markets, supra note 37.

117. PPI 208 (Table V-2).

118. See note 93 supra and accompanying text.

119. PPI 56. 
lies in its being used so as best to contribute to the value of each share, an effect which might not follow from increasing the fund's size. ${ }^{120}$

The difficulty with the investor's position has been that, prior to Moses, there was no clear-cut, uncomplicated way in which the excess brokerage could be captured for his benefit. Indeed, if there were, the adviser's duty of loyalty, proscribing the usurpation of corporate opportunity, would likely force him to recover for the fund. ${ }^{121}$ The various methods in use by some funds, or proposed by the SEC or shareholders, all involved either business commitments or unresolved legal questions. ${ }^{122}$ Whether these methods of recapture should be adopted therefore fell within the business judgment category, protected from judicial review by the rule which allows honest business decisions to be set aside only where clearly unreasonable. Thus, although the problem was flagged by the 1962 Wharton study of the mutual fund industry, ${ }^{123}$ no shareholder suit on the subject reached decision until 1970, and in that case the district court held that no common law fiduciary duty was breached by use of brokerage to reward sales effort. ${ }^{124}$ As for administrative protection, the SEC took the position that easy legal methods of recapture did exist, ${ }^{125}$ but it based no complaints on this proposition. Rather, the SEC directed its attention to the source of the problem-the minimum brokerage commission schedule and exchange rules permitting flexible use of the excess portion of minimum commissions. ${ }^{126}$ As of spring, 1972, its efforts have resulted in reduced fees for large orders and in abolition of the give-up. ${ }^{127}$ For the future, the SEC recently announced its

120. See notes $87-90$ supra and accompanying text.

121. The SEC expressly adopted the position that fiduciary duty would require recapture if it were readily available, in Securities Exchange Act Release No. 8239 (Jan. 26, 1968). This release proposed rule $10 \mathrm{~b}-10$. See note 127 infra.

122. See Moses v. Burgin, 316 F. Supp. 31, 41-48, 56-58 (D. Mass. 1970); PPI 172-73; note 140 infra and accompanying text.

123. WhaRTON REPORT 33.

124. Moses v. Burgin, 316 F. Supp. 31 (D. Mass. 1970) (Wyzanski, J.). The complaint in this case was filed in Dec., 1967. An earlier suit, brought in May 1967, and settled in Dec. 1967, also involved use of give-ups to reward salesmen, but this apparently was not a major issue. The settlement provided, inter alia, that no give-ups would be directed unless they were credited against amounts the fund owed the adviser. Wall St. Journal, Dec. 18, 1967, at 11, col. 1 .

125. 445 F.2d at 377-78; PPI 173.

126. Future Structure; PPI 186-89.

127. Both a revised fee schedule and the abolition of give-ups resulted from negotiations between the exchanges and the SEC following SEC Securities Exchange Act Release No. 8239 (Jan. 26, 1968). This release proposed rule 10b-10, which would have eliminated only those 
intention to go much farther in this direction. ${ }^{128}$ However, for now, excess is still available to be used as a sales reward, ${ }^{129}$ and the giveup has been replaced by other means of transporting the excess to mutual fund salesmen. ${ }^{130}$ Thus, pending the results of the SEC's

customer-directed give-ups which were not recovered for the mutual fund. An account of the demise of the give-up may be found in Independent Broker-Dealers' Trade Ass'n v. SEC, 442 F.2d 132, 134-36 (D.C. Cir. 1971).

128. The relevant points of this wide-ranging statement arc the intention to eliminate minimum brokerage commissions on institutional orders, see note 129 infra; the announcement that NASD shall formulate rules prohibiting fund salesmen from receiving compensation through portfolio transactions, FUTURE STRUCTURE 7; and the plan to prohibit exchange membership of brokers whose primary function is to recapture commissions for an institutional investor, or who do not obtain most of their business from persons other than their affiliated institutions, $i d$. at 8-9. As for the last point, a regional exchange immediately announced that it would not cooperate with the SEC, and one affectcd brokerage affiliate told the exchanges of which it was a member that it would bring antitrust actions against them if they complied with the SEC's demands. 139 BNA SEC. REG. \& L. REP. A-12 (1972). Further, the prohibition of institutional membership has drawn the opposition of Senator Harrison A. Williams (D. N.J.). For a report of thc heated hearings on the subject by the Senate Subcommittce on Securities in April 1972, see 149 BNA SEC. REG. \& L. REP. A-8 (1972); 148 id. A-10.

129. There should no longer be any excess in brokerage paid on very large transactions; for where a $\$ 500,000$ transaction is accomplished with one broker in one day, the commission may be negotiated free of any exchange rule minimums. Further, in its Statement on the Future Structure of the Securities Markets, the SEC has indicated its desire to eliminate eventually fixed minimum commission rates on institutional-sizc orders. To this end, it announced an initial reduction to $\$ 300,000$ of the breakpoint between fixed and negotiated rates to take cffect in the spring of 1972, and Chairman Casey has stated that a reduction to $\$ 100,000$ must be effectuated by the spring of 1974. I44 BNA SEC. REG. \& L. REP. A-13 (1972).

That negotiated commissions may lead to use of other devices to reward sales effort was suggested by SEC Chairman William J. Cascy in a speech reported at 107 BNA SEC. REG. \& L. REP. D-1 (1971). In particular he thought it possible that funds were using secondary distributions for this purpose. In a secondary distribution a large block of portfolio shares is sold outright to a group of brokers who then resell them at a profit to their customers. The cffective cost to the fund is usually much greater than in a normal transaction in which the broker's compensation is the brokerage commission. That all such devices for compensating salesmon through portfolio transactions will come under SEC attack was made clear in the SEC's Statement on the Future Structure of the Securities Markets, FutURE STRUCTURE 7.

130. The usefulness of the give-up for directing excess brokerage to salesmen was twofold. First, on 6 of the 7 regional exchanges the givc-up could be directed to virtually any securities dealer whether or not he was a member of the exchange. See note 112 supra. In the case of salesmen who are exchange members, other moderately casy ways of transporting the excess are available. One method is the "reciprocal," in which the fund places an appropriate amount of brokerage business directly with thc broker/salesman. Another is to direet $40 \%$ "clearing commissions" to the broker/salesman, putatively as compensation for having accepted legal responsibility for clearing the trade (although the recipient does nothing and learns of the trade only upon receipt of his commission). Thus the abolition of the give-up has resulted in more securities salesmen seeking exchange membership, and in loosening of the membership requirements of the regional cxchanges (since one of their prime weapons for competing with the N.Y. Stock Exchange for fund business is their willingness to allow the excess brokcrage to reach whomever fund managemcnt wishes to reward). See Welles, The War Between the Big Board 
current activities, the conflict of interests between advisers and investors over the use of brokerage commissions remains an issue, and as is true of the other areas of conflict discussed above, legal assurances of investor protection in its resolution are nonexistent. ${ }^{131}$

The foregoing discussion has underlined areas in which the adviser and the investors have conflicting interests, but to which neither legislation nor traditional fiduciary duties extend. In short, they present opportunities for the adviser and his board to choose as they please, and so long as their choice stays within business judgment boundaries they are immune from challenge. The extent to which the investor's interest will affect the outcome turns not on his legal rights but on the integrity and diligence of the manager and other members of the board of directors. It is in this context that Moses v. Burgin acquires potential significance.

\section{Moses v. Burgin}

In Moses, the court faced the issue just discussed-what, if any, limitations confine an adviser's use of fund brokerage. It is a confus-

and the Regionals, INST. INveSTOR, Dec. 1970, at 21. See also Independent Broker-Dealers' Trade Ass'n v. SEC, 442 F.2d 132 (D.C. Cir.), cert. denied, 404 U.S. 828 (1971) (suit by nonexchange members challenging the abolition of give-ups).

Second, the give-up was used even where the recipient was an exchange member in order that the fund could use the brokerage services of the largest and most efficient brokers, called "lead brokers," but could still direct the excess to smaller, less efficient brokers who rendered such services as research or sales effort. Abolition of the give-up has forced funds to reward broker/salesmen with direct placement of small orders (the reciprocal). This has resulted in the detcrioration of the lead broker system, despite its claimed advantages of efficiency and best execution. [This material is derived from comments of various panelists at the Briefing Conference on Recent Developments under the Investment Company Act, Sept. 30, 1971, Washington, D.C., sponsored by the Federal Bar Association and Bureau of National Affairs. Similar information may be found at PLI CONFERENCE 99-106 (comments of Elkins Wetherill concerning the Philadelphia-Baltimore-Washington Exchange)].

131. As discussed below, see notes 141-43 infra and accompanying text, Moses v. Burgin held that one method of recapture did not involve countervailing business or legal considerations. However, this method was dependent on the customer-directed give-up, which was eliminated in 1968. Thus the issue of recapture of brokerage commissions is now back in the realm of business judgment. For a discussion of currently possible methods, and their attendant difficulties, see Miller \& Carlson, supra note 84 , at 55-71. All such methods of course have uncertain life spans, due to the SEC's Statement on the Future Structure of the Securities Markets. See note 128 supra and accompanying text.

One method not discussed by Miller \& Carlson, but which may be so riskless and inexpensive as to involve no countervailing business judgment considerations, is available under Pacific Exchange Rule IV, $\S 2$. This rule allows a $25 \%$ discount on brokerage commissions to "preferred nonmembers." Such status may be acquired by NASD members upon payment of a $\$ 100$ fee. 
ing case, combining a complex fact situation with uncertain legal theories. The uncertainty of the theories applied arises from the court's reluctance to take a step which plaintiff urged and which other courts had taken -that of reading common law fiduciary standards into the Investment Company Act. ${ }^{132}$ Refusing to take this step, the court searched for other duties that might be implicit in the Act. It found a duty in the adviser to disclose to the unaffiliated directors information about every area in which there "was even a possible confict" of the adviser's interest with that of the investors. ${ }^{133}$ The court did not go very far towards explicating the legal effect of this duty and failed to apply it consistently. ${ }^{134}$ Nevertheless, it is the contention of this Comment that the First Circuit has recognized a duty substantially stricter than any disclosure duties that exist under the common law. After discussing Moses itself, the balance of this piece will explore the outlines of this implicit duty to disclose. It is suggested that, by requiring exhaustive disclosure of various courses of action open to a mutual fund, and of management interest in any of them, the court has enhanced investor protection as to those mutual fund decisions which are presently beyond challenge. The duty seems to assure that disinterested directors, who under the 1970 amendments should be more independent of the adviser, ${ }^{135}$ will be both better-equipped to serve the investors and more sensitive to their interests.

The primary basis of the complaint in Moses was failure of the adviser and board to utilize allegedly available methods of recapturing brokerage commissions used to promote sales of the fund's shares, ${ }^{136}$ a use which is of substantial benefit to the adviser, as discussed above. ${ }^{137}$ Plaintiff suggested two methods of recapture for the fund. First, plaintiff urged that the adviser should have created a brokerage affiliate which could both execute fund portfolio transactions and receive, as an exchange member, the excess portions of commissions earned by other brokers; these commissions would then be credited against the advisory fee owed by the fund. The fund's

132. 445 F.2d at 376 . See notes $45-50$ supra and accompanying text.

133. 445 F.2d at 376.

134. See text accompanying notes $179-80$ infra, dealing with the court's treatment of the issue of creating a brokerage affiliate to effect recapture.

135. See notes 10,40 supra and accompanying text for a discussion of the amended requircment for "disinterested" directors.

136. 445 F.2d at 372.

137. See notes 114-19 supra and accompanying text. 
board had early considered and rejected a brokerage affiliate to execute transactions, although it had not considered the possibility of using it to receive give-ups. Plaintiff's second suggestion was to use the rule then existent on most regional exchanges-allowing a giveup to be directed to any member of the National Association of Securities Dealers (NASD), to which all underwriters belong-such that all give-ups for transactions on those exchanges would be directed to the adviser's underwriting affiliate, even though the affiliate was neither a broker nor an exchange member. As with the first method, commissions recaptured by the affiliate would be credited against the advisory fee owed by the fund. Finally, plaintiff complained of the adviser's failure to fully inform the unaffiliated directors about these methods of recapture. ${ }^{138}$ Each of these complaints was grounded on alleged breaches of fiduciary duties imposed by the 1940 Act and the common law. A full trial on the issue of liability resulted in a judgment for the defendant on all the issues raised. The basis for the judgment was the finding that each of the methods of recapture advanced by plaintiff were either illegal under exchange rules, or required such extensive business involvement and risks that the decision not to use them was protected by the business judgment rule. ${ }^{139}$

The First Circuit agreed that there was no duty to establish a brokerage affiliate to accomplish recapture, for a brokerage business involves substantial risks and fundamentally different operational problems, and is generally "not a matter to be lightly undertaken."140 As to the second proposed method of recapture, that of NASD recapture, the court and the parties apparently agreed that it could have been instituted with no changes in the structure or basic commitments of the fund, the adviser, or the adviser's underwriter affiliate. All that would have been required was for the adviser to direct the fund's brokers to send to the underwriter give-ups for transactions they executed on those regional exchanges permitting such an arrangement. However, the defendants insisted that the anti-rebate rules on all exchanges would prevent these give-ups from being credited

138. 445 F.2d at 372 .

139. Moses v. Burgin, 316 F. Supp. 31, 57-58 (D. Mass. 1970); 445 F.2d at 381 .

140. 445 F.2d at 374-75. The SEC has taken this same position, that creation of a brokerage affiliate is a matter of business judgment. Letter of SEC General Counsel Philip A. Loomis, SEC Securities Exchange Act Release No. 8746 (Nov. 10, 1969). For a somewhat critical discussion of the basis of the business decision not to form a brokerage affiliate, see Glazer 249-50. 
against the advisory fees owed by the fund. ${ }^{141}$ While this contention had been accepted by the district court, the court of appeals ruled that the exchanges had the power to interpret their own rules to allow NASD recapture. ${ }^{142}$ In fact, by 1968 two exchanges had indicated that they would permit the practice. ${ }^{143}$

Defendants argued that even if there were a method of recovering commissions which provided no countervailing business judgment considerations, such as cost, risk, or changes in structure of operations, they would still not be under a duty to use that "free" method. ${ }^{14}$ They based this contention on yet another business judgment claim, that use of recoverable give-ups to promote sales would be a legitimate business decision on behalf of fund investors. This argument was apparently based on the concept that sales in excess of redemptions are necessary if a fund is to maintain control of its investment decisions. ${ }^{145}$ Without addressing itself directly to this issue, the court relied on a requirement in the fund's charter that net asset value be received for all shares issued to investors. ${ }^{146}$ The court reasoned that this requirement prevented existing investors from bearing the expense of selling shares to new investors, leaving all sales expenses to be borne by the purchasers of new shares. It found that if the fund was paying more for brokerage commissions than was necessary, in order to generate sales, then indirectly the existing shareholders were paying for the cost of sales and the charter was thereby being violated. In short, the court found that within the fund's charter no leeway existed for the business decision to use the excess portion of brokerage commissions for sales, if recovery was freely available.

At this point in its reasoning the court had determined that recovery of excess brokerage was freely available and that the defendants had no business judgment defense. What remained for determination was whether failure to recapture breached any duty owed to the fund and its investors. Plaintiff pressed upon the court "the familiar general principles governing fiduciaries in the area of self-dealing." 147 However, the First Circuit was unwilling to accept the proposition

141. 445 F.2d at 376.

142. Id. at $381-82$.

143. Id. at 376,382 .

144. Id. at 373-74.

145. See note 89 supra.

146. 445 F.2d at 374.

147. Id. at 376. 
that these duties had been incorporated in the 1940 Act. ${ }^{148}$ Instead, the court found that the defendants had violated a duty imposed by the requirement in section 10 of the 1940 Act-that there be a minimum number of unaffiliated directors on all fund boards. ${ }^{149}$

\section{The Duty of Section 10 Disclosure}

The court approached section 10's requirement for unaffiliated directors in the context of the congressional finding that the national public interest is adversely affected when investment companies are run for the benefit of persons other than investors. ${ }^{150}$ It noted that in the setting of the mutual fund, unlike the ordinary business or trust, "management's normal activities are frequently touched with selfinterest," 151 thus making it very unlikely that management would consistently run the fund solely in the interest of investors. Part of the congressional answer to this danger was to provide for mandatory, independent watchdog directors. Implicit in this solution, as the First Circuit read it, was the requirement that these unaffiliated directors be "furnished with sufficient information so as to enable them to participate effectively in the management of the investment company." 152 Thus the court considered unavoidable the conclusion that management is under "a duty of full disclosure of information to these unaffiliated directors in every area where there was even a possible conflict of interest between their interests and the interests of the fund." 153 In Moses, the management had been fully alerted to the possibility of NASD recapture, and thereby to their conflict of interest, by SEC staff members, the PPI, and their own counsel. ${ }^{154}$

148. Id. at 373,376 .

149. Id. at $376-77,381$. See note 10 supra. The court did not entirely create its approach without the assistance of counsel. That a "requirement of full and fair disclosure" might be implicit in section 10 was suggested in plaintiff's brief, but in a limited context. As used by plaintiff this duty was one element of one counter to the defense that the arrangement had received independent director approval. See notes $65-67,71$ supra and accompanying text. The unaffiliated directors' lack of independent knowledge was treated as one indication that they were controlled by management, and being controlled they could not make a legally valid busincss judgment on the issue. Brief for Plaintiff-Appellant at 102-04. There being no valid approval by the independent directors, the adviser had thus breached his duty of loyalty, for the adviser himself had a conflict of interest as to how to use the brokerage. Id. at $94 \mathrm{~A}$.

150. 445 F.2d at 376.

151. Id.

152. Id. at 377 , quoting from Imperial Financial Servs., Inc., CCH FED. SEC. L. REP. If 77,287, at 82,464 (SEC I965).

153. 445 F.2d at 376.

154. Id. at 377-8I, 383-84. 
Thus they breached the duty implicit in section 10 by failing to disclose that NASD recapture was a possible alternative to the use of excess brokerage for sales promotion. As a result they became liable to the fund in the amount of all commissions which could have been recaptured since the time they should have become aware of their conflict. ${ }^{155}$ In setting this measure of damages, the court ruled that because management's concealment of NASD recapture had prevented the matter from being considered at an earlier time, they would not be given the benefit of the possibility that either the unaffiliated directors or the participating exchanges would not have approved the scheme had it been proposed at an earlier date. ${ }^{156}$

A duty of disclosure to disinterested directors is not a new creature to the law. As noted above, it has long existed as an aspect of the duty of loyalty when directors or managers are faced with a conflict of interest, ${ }^{157}$ and approval by a disinterested board under conditions of full disclosure has, since the early part of this century, been a defense that would support the validity of a fair contract with a director. ${ }^{158}$ The significance of the disclosure required in Moses is that apparently it is more demanding than that required in existing common law cases. True, the Moses court thought the facts of the case sufficient to invoke the routine common law duty to disclose ${ }^{159}$ - such a common law duty would seem to require only disclosure of management's interest in the use of give-ups for sales promotion but not disclosure of alternative uses. However, the nature of the implicit duty described in Moses differs significantly from the common law duty. For example, in developing its disclosure requirement, the court referred to the general common-law fiduciary duties, saying:

We do not denigrate these principles, though we [hold that they are not necessarily incorporated into federal law]. We believe, however, that the Act imposes a more fundamental and pervasive requirement where, because of the structure of investment trusts, self-dealing is not the exception but, so far as management is concerned, the order of the day. ${ }^{160}$

Again, the court referred to the "special burden" implicit in the 1940 Act, stating that the management defendants were under a full duty

155. Id. at 385.

156. Id. at $384-85^{\circ}$.

157. See note 71 supra and accompanying text.

158. See note 64-67 supra and accompanying text.

159. 445 F.2d at 383 .

160. Id. at 376 (emphasis added). 
of disclosure, "whatever may be the duty of disclosure owed to ordinary corporate directors . . . "161 In addition to these statements indicating the demanding nature of the implicit federal requirement of disclosure, the logic by which the duty was derived suggests that it goes considerably beyond the type of disclosure heretofore required. The disclosure demanded is that necessary to enable the disinterested directors to exercise independent judgment as to fund policies that are possibly touched with management self-interest. It is for this reason, said the court, that Congress provided for independent directors, and it is to this end that the courts must assure their being informed. ${ }^{162}$ Thus the standard that is discernible is a pragmatic one-whether management has provided sufficient information to assure "effective participation" of the independent directors, such that the fund is operated for the benefit of investors. By applying this standard to the situations discussed above, involving management decisions which are apparently beyond legal challenge, the extraordinary nature of the Moses duty to disclose becomes apparent.

For example, to effectively determine that decisions about the proper size of a fund are made in the interest of the investors, ${ }^{163}$ the independent directors must be apprised of any delays in execution of orders, differences between execution price and the market price when the transaction is initiated, occasions on which difficult execution affects portfolio selections, changes in these factors as the fund has grown, and comparisons of the fund's experiences with those of closed-end funds ${ }^{164}$ and with other mutual funds of different sizes. Similarly, to participate effectively in setting the adviser's fee, ${ }^{165}$ the disinterested directors should be aware of all the adviser's income attributable to the fund, such as for brokerage or underwriting services provided by an affiliate; they should understand the effect on the fee of other fund policies, such as heavy sales loads and use of brokerage commissions to encourage sales; and they should be provided' information as to changes in the profitability of the adviser's

161. Id.

162. Id. at 376-77.

163. See notes 86-91 supra and accompanying text.

164. A "closed-end" fund does not continuously offer to redeem its shares at net asset value. Rather, as with investments in securities of normal corporations, money invested in a closed-end fund is permanently committed to the fund, subject to the willingness of other investors to buy the shares from the original investor. While legally capable of continuously offering new shares for sale to the public, most closed-end investment companies do not do so, PPI 42, and over a period of time, their size tends to be relatively constant.

165. See notes 75-85 supra and accompanying text. 
operation as the fund has grown, as well as information about comparative cost and performance of investor alternatives, such as bank trust departments and other mutual funds. ${ }^{168}$ In order to participate effectively in determining the proper sales load, ${ }^{167}$ a director would need to know the desirability of further fund growth, as just discussed, and the extent to which existing shareholders are responsible for purchases of additional fund shares. When considering dividend policies, ${ }^{168}$ in order to protect effectively the investors' interest against that of the adviser, the disinterested director must know of any effect the dividend policy may be having on portfolio transactions; the nature and source of complaints when distributions are reduced; and whether there are any efforts to inform investors of the advantages of retaining capital gains within the fund. Finally, as to use of the excess portions of minimum brokerage commissions, so long as they continue to exist, ${ }^{169}$ the independent director should know of all possible methods of recapture as required in Moses. ${ }^{170}$ Of particular significance, because give-ups have been abolished, is information about the benefits and difficulties of establishing a brokerage affiliate, ${ }^{171}$ and the experiences of comparable funds which have used this device to reduce brokerage expenses.

The type of information listed in the proceding paragraph is necessary if independent directors are to exercise effective independent judgments on those matters of mutual fund policy. ${ }^{172}$ Further, management may not assume that this sort of information is possessed by independent directors in light of the reminder in Moses that disin-

166. It is likely that such information pertaining to the advisory fee is required indepen. dently of Moses by the 1970 amendments. Sec note 198 infra and accompanying text.

167. See notes 92-99 supra and accompanying text.

168. See notes 100-04 supra and accompanying text.

169. See note 129 supra.

170. See note 131 supra.

171. See note 140 supra and accompanying text.

172. In his discussion of the "duties and responsibilities" of the unaffiliated director, Robert H. Mundheim states that the 1940 Act imposes on them "heavy and broad" responsibilities. Mundheim 1062. He discusses the matters they should consider to fulfill properly their overseer role, and concludes that they "must acquire a relatively sophisticated knowledge" of mutual funds. Id. at 1071. However, his is a normative approach, prescribing what the unaffiliated director ought to do, but never identifying any legal requirements that certain matters be considered or that the "sophisticated knowledge" be obtained or provided. Moses supplies the duty that fills this gap.

A similar comment appropriately describes Glazer's discussion of inquiries a director should make to assure that each fund in a complex is being fairly treated by the common adviser. See Glazer 233-41, 277-82. However, he does make the suggestion that these inquiries could follow from the duty of care. Id. at 234. 
terested directors will not be particularly experienced in the special problems of mutual fund operaton. ${ }^{173}$ It seems obvious that information of this nature is on a different level of sophistication and detail and involves greater attention to alternatives, than that required in typical common law disclosure cases, which deal, for example, with the failure of a bank president to disclose that his efforts to secure a loan for a new corporation were in consideration of his personal receipt of its shares, ${ }^{174}$ or with a corporate officer's failure to reveal that he was organizing a competing company. ${ }^{175}$ Of course the disclosure required by section 10 may be thought of as a logical extension of the common law cases-after all, much more information is necessary if independent directors are to properly evaluate give-up practices than is needed if the issue is a corporate officer's interest in a competitor. The common law duty of loyalty could be interpreted, given the complexities and frequency of mutual fund conflicts of interest, to require very extensive disclosure. Whether or not it does so, however, the significance of Moses stands-federal law now requires mutual fund advisers to provide the information needed by the independent directors to participate in the fund's management with such effectiveness as to assure that the fund is run solely for the benefit of its investors.

\section{Unresolved Questions About Section 10 Disclosure}

The duty of section 10 disclosure makes its first full-blown appearance in Moses. ${ }^{176}$ However, the dimensions are left quite unclear. On two major issues the Moses court offers some guidance, but only in an equivocal and, at times, contradictory manner. Pending future decisions, one can only discuss these critical areas, explore

173. 445 F.2d at 377. It is noteworthy in this regard that in Moses the full burden of informing the unaffiliated directors of NASD recapture was borne by the management, despite the information having been placed in the public domain by the PPI-the unaffiliated directors were specifically held entitled to rely on management and thus not to have breached their duty of care. Id. at 384.

174. See Blum v. Fleishhacker, 21 F. Supp. 527 (N.D. Cal. 1937), modified, 109 F.2d 543 (9th Cir.), cert. denied, 311 U.S. 665 (1940).

175. See Craig v. Graphic Arts Studio, Inc., 39 Del. Ch. 447, 166 A.2d 444 (1960); Duane Jones Co. v. Burke, 306 N.Y. 127, 117 N.E.2d 237 (1954).

176. That a duty of disclosure is implicit in section 10 of the Investment Company Act had been suggested in an earlier SEC case, Imperial Financial Servs., Inc., CCH FED. SEC. L. REP. II 77,287 (1965). However, in that case the duty was not the primary basis of liability. In Imperial the investment company's prospectus was misleading and incomplete in that, inter alia, it failed to state that the unaffliated directors were not informed of various questionable transactions not mentioned in the prospectus. 
their resolution in Moses, and apply to them one's own concept of appropriate public policy. This Comment will close with such an approach to the questions of the burden of showing damage caused by the breach of the duty and the effect of satisfying this duty on the other duties of both the management and the independent directors.

Assuming breach, what burden of showing damage? The practical effect of section 10 disclosure on litigation will turn largely on whether the plaintiff is saddled with the burden of showing that, had there been disclosure, the disinterested directors would have decided an issue differently. Proving that something would have happened differently than it did would seem to be extraordinarily difficult, especially where such proof depends on the testimony of disinterested directors who are likely to have a certain sympathy for the management which normally controls their appointment. ${ }^{177}$ In Moses the court relieves the plaintiff of the burden of proving causation, noting that management was responsible for the issue's failure to come up for decision by the board of directors under conditions of full disclosure. ${ }^{178}$ The case, however, is inconsistent on this point. When the plaintiff suggested the establishment of a brokerage affiliate to accomplish recapture, the lower court found legitimate business reasons to support the board's decision not to do so, and the First Circuit found no error. ${ }^{179}$ In making this ruling, however, the appellate court failed to confront the fact that the independent directors were unaware that such an affiliate could reduce brokerage costs not only by executing portfolio transactions, but also by receiving give-ups on transactions executed by other brokers. Displaying no recognition that this presented the same issue as that on which liability was based in the NASD recapture setting; the court explained that there was no evidence that the undisclosed facts would have made any difference to the directors' decision. ${ }^{180}$

The only reason for different treatment of the burden of proving causation in the brokerage affiliate setting would appear to be that

177. "[W]ho appoints an unaffiliated director? In 90 per cent of the cases, perhaps more, he is selected by the management ...."PLI CONFERENCE 285 (comments of Allan F. Conwill). Directors of course are eleeted by the shareholders. However, typically management both proposes new directors, Jaretzki 783, and controls the proxy machinery by which they are elected. Wharton Report 68; 119 BNA SEC. REg. \& L. REP. B-1, 2 (1971). Cf. Eisenberg \& Phillips 77. A noted plaintiff's counsel puts it as follows: "The affiliated men pick the unaffiliated men." U. PA. Conference 739 (comments of Abraham L. Pomerantz).

178. 445 F.2d at 385.

179. See note 140 supra and accompanying text.

180. 445 F.2d at 375 . 
genuine issues of business judgment were involved in deciding whether to create a brokerage affiliate, whereas NASD recapture was "freely available" and, under the fund's charter, had to be adopted. ${ }^{181}$ This seems to suggest one of two conclusions: either (1) the burden of showing causation (that a different decision would have occurred but for the failure to disclose) lies with the plaintiff when the decision involves a business judgment; or (2) the court, having already found liability in management's failure to use NASD recapture, was ill-disposed to even appear to suggest a duty to create a brokerage affiliate, was uncertain as to exactly what its new duty entailed, or perhaps was not aware that the duty could be applied to the broker affiliate question. It is here contended that the second is the more reasonable explanation. To place the burden on the plaintiff only where the decision involves business judgment is to emasculate section 10 disclosure in just the situation for which it is designed-decisions where investor protection must be present in the decision-making process, for once made they are beyond legal challenge. To do so would ignore the basis of the duty of section 10 disclosure, that Congress intended there to be effective watchdogs in a situation where self-dealing, so far as management is concerned, is "the order of the day." 182 Another reason for accepting the second explanation of the burden-of-causation inconsistency is simply that the development of the Moses decision is occasionally uncertain and its reasoning is not uniformly tight. ${ }^{183}$ Additionally, support for the proposition that the plaintiff should not bear the burden of establishing that disclosure would have made a difference is found in the Supreme Court's recent decision in Mills v. Electric Auto-Lite, ${ }^{184}$ a derivative action challenging a corporate merger on the ground that stockholder approval was obtained through a misleading proxy solicitation. The court below had ruled that if the transaction were fair it would be presumed that the misleading solicitation made no difference to stockholder approval. ${ }^{185}$ The Supreme Court reversed and applied a prophylactic rule facilitating private enforcement of stockholder ratification requirements, thereby implementing congressional intent to provide for fair corporate suffrage. The rule propounded

181. Id. at 374.

182. Id. at 376. See notes $150-53$ supra and accompanying text.

183. See, e.g., note 188 infra. The rather scattered nature of the Moses opinion has been commented on elsewhere. See Lipton, supra note 8 ("a very poorly reasoned opinion").

184. 396 U.S. 375 (1970).

185. Id at 380 . 
was that, notwithstanding fair terms, the stockholder establishes causation if he merely shows that minority shareholder votes were necessary to approve the merger and that the proxy solicitation for these votes contained a material misstatement or omission. ${ }^{180}$ Thrust into the Moses setting, this rule would mean that management is deemed to have caused damage when it fails to supply information needed for the independent directors to participate effectively in decisions involving management conflicts of interest.

When an issue is disclosed, what duties remain? Moses does not deal with the duties borne by management and disinterested directors with regard to an issue which has been properly disclosed. The reason for this is twofold. First, it was unnecessary due to the fund's utilization of NASD recapture once its feasibility was disclosed. ${ }^{187}$ Second, to the extent the court felt compelled to approach the issue, it ducked behind the argument that, under the fund's charter, there was no choice but to adopt the recovery method. ${ }^{188}$ The charter argument aside, the decision seems to recognize at several points that the disinterested directors would be free to decide as they wished on the basis of the information they received. ${ }^{189}$ Since the questions involved are ones of business judgment, to hold otherwise would substitute judicial fiat for business discretion. The only constraint on the independent directors' decision apparently would be their existing duty of care, based in the common law and probably incorporated into federal law

186. Id. at 385. See also Affiliated Ute Citizens v. United States, 40 U.S.L.W. 4448 (U.S. Apr. 24, 1972), where it was held that proof of reliance was unnecessary for a $10 \mathrm{~b}-5$ recovery when undisclosed faets were material, that is, when "a reasonable investor might have considered them important in the making of his decision." Id.

187. 445 F.2d at $380-81$.

188. Id. at 373-74. The exact role of the charter argument is actually rather mystifying. If the duty violated was that of disclosure, and if the scope of the required disclosure is as great as the court indicates, the charter argument seems superfluous. It would be critical if liability were based on the failure to decide to effect recapture, and it was in this context that plaintiff introduced the issue, as the last point in its 115-page initial brief. Brief for Plaintiff-Appellant at 105-07. (For plaintiff the charter argument was necessary if the court found that the directors had made an otherwise valid business decision not to recapture, but the emphasis of plaintifis case was that no such valid decision had been made.) However, in the court's ruling the basis of liability was failure to disclose the possibility of recapture, preventing the independent directors from making a business decision. That there might have been a eharter provision predetermining the outcome of that decision is irrelevant. See note 183 supra and accompanying text.

189. $445 \mathrm{~F} .2 \mathrm{~d}$ at 383 (that it was for the unaffiliated directors to determine whether or not to experiment with recapture methods); $i d$. at 385 (that the court would assume that, had disclosure been made earlier, the unaffiliated directors would have decided at that time to recapture). 
by the amended section 36(a) standard of "fiduciary duty involving personal misconduct." "190 As discussed above, within the realm of legitimate business decisions, the effect of this duty is virtually nil. ${ }^{191}$

As for the adviser, the case seems to assume that he will be bound by the decision of the disinterested directors. ${ }^{192}$ This goes beyond the proper role of the duty of section 10 disclosure and fails to consider the economic relationship between the adviser and the fund. It should be noted that the adviser is technically a contractor hired by the fund to perform advisory functions. As such he has freedom to choose not to be the fund's adviser if he is dissatisfied, for example, with his fee, with fund policies relating to growth and sales, or with the fund's insistence that he establish a brokerage affiliate. ${ }^{193}$ Further, the adviser seems perfectly free to insist on policies which he knows may be less favorable to the investors' interests, so long as the terms which he obtains comply with the fiduciary duty standards of the common law and section 36 . That a fiduciary has always had this right, to get what he can within limits, is quite clear in the context of his bargaining for his own compensation. ${ }^{194}$ That Moses does not affect this right follows from the basic nature of section 10 disclosure. The duty found by the Moses court does not require that different policy decisions be made. Unlike the standards of reasonableness, fairness, or waste, it does not serve to set limits on the exercise of business discretion. Rather, it assures that decisions within the limits of these other stan-

190. See note 52 supra and accompanying text.

191. See notes 53-62 supra and accompanying text. This Comment does not suggest that the duty of care should impose greater burdens on independent directors. The author is aware that this would require greater judicial involvement in business decisions, and is cognizant of the argument that great burdens can seriously restrict the supply of persons who are qualified and willing to serve as directors. See Jaretzki 792-94. For a criticism of increasing the scope of judicial involvement in the mutual fund setting, see Modesitt 1268-71.

192. See note 189 supra. 445 F.2d 369, 375 (that the unaffiliated directors had long decided against a brokerage affiliate).

193. In practice this freedom of the adviser to resign is the limit on the bargaining power of the independent directors. Presumably shareholders have invested with the fund in reliance on the existing adviser, and do not expect the directors to cause his departure except in unusual circumstances. Further, section 15(a) of the 1940 Act, 15 U.S.C. $\S 80 \mathrm{a}-15$ (a) (1970), requires the rather cumbersome procedure of stockholder approval before a replacement could assume the advisory duties. "A presumption results in favor of the continuance of the existing adviser. The theoretical discretion of the board of directors is thus severely limited in actuality." Jaretzki 786. See U. PA. Conference 757-58 (comments of Philip A. Loomis, Jr.).

194. So long as he bargains at arm's length, the fiduciary-to-be may seek to obtain a better bargain. This has led some lawyers to suggest that the adviser is not a fiduciary with respect to the management fee. See U. PA. Conference 744-45, 753 (comments of Alfred Jaretzki, $\mathrm{Jr}$.); id. at 758 (comments of Robert M. Loeffler, Jr.). 
dards are made with an eye to investor interests. It does this not by directly affecting the permissible substance of the decision, but rather by improving the method of making it.

The basic premise of section 10 disclosure is that when management and the disinterested directors decide fund policies, the results will better conform to the investor's interests if the watchdog directors receive information which alerts them to areas where they should bargain for concessions, and which generally sensitizes them to the need for such concessions. In the end, their intelligence, diligence, and integrity will determine the effectiveness of the duty. ${ }^{105}$ Heavier reliance on the disinterested directors seems appropriate and even necessary since mutual fund investor protection has reached the stage where, despite rampant opportunities for abuse, the investor's interests are well-protected except as to matters involving business judgments. ${ }^{198}$ Congress itself has recognized that the independent directors should be strengthened, as evidence by the 1970 amendment requiring that the directors not be "interested" persons. ${ }^{197}$ Further, Congress is aware that adequate information is essential to their proper functioning, as indicated by two other amendments. One of these specifically imposes a duty on both management and the directors to assure that the directors have "such information as may reasonably be nccessary to evaluate the terms" of the advisory

195. An occasional writer reminds us that businessmen by and large wish to be thought of as doing what is "right," and that independent directors have considerable resources of persuasion and publicity that they can bring to bear on management. See Mundheim 1068. For a discussion of the role of one fund's independent direetors, see U. PA. CONFERENCE 741 (comments of Joseph E. Welch).

196. The first half of this Comment surveys the state of mutual fund investor protection. The need for greater reliance on the disinterested director was recognized in a recent article which proposed several ways to assure the reasonableness of mutual fund advisers' fees. One of its suggestions was that the independent directors be made truly independent through SEC selection, and assignment to each fund, from a pool acceptable to the mutual fund industry. Glick, supra note 87, at 1482-83. See also 144 BNA SEc. REG. \& L. REP. A-4 (1972) (report of Robert Mundheim's comments concerning the importance of stronger independent dircctors).

197. 15 U.S.C. $\S 80 \mathrm{a}-2(\mathrm{a})(19), 10$ (a) (1970), formerly ch. 686 , tit. I, $\S 2(\mathrm{a}), 10(\mathrm{a}), 54$ Stat. 790, 806 (1940). Congress' intent in this regard is clearly expressed in the amendment's legislative history. Thus the Senate committee report contains a section entitled Strengthening Independent Checks on Investment Company Management. Within that section it is stated:

The function of [unaffiliated directors] is to supply an independent check on management and to provide a means for the representation of shareholder interests in investment company afiairs. Your committee believes that the definition of an "affiliated person" in [the original act] does not adequately meet this purpose. SENATE REPORT 32.

Identical language appears at House REPORT 13. 
contract. ${ }^{198}$ The second requires that the disinterested directors vote in person at directors' meeting dealing with selection of the adviser, the underwriter, and the independent auditor; ${ }^{199}$ this amendment "is intended to assure informed voting on matters which require action by the board of directors . . . ."200

Hopefully the role of watchdog director will be filled more effectively due to the convergence of better information, as assured by Moses, more highly independent directors as provided by the 1970 amendments, and a prudent concern for the investor born of a continuing rash of derivative suits. ${ }^{201}$ On the other hand, if these changes only make the process look better, but do not produce better results, then they may be positively detrimental to investor protection-for as the process acquires more of the appearance of arm's length bargaining between directors and management, the courts are likely to become less willing than ever to upset the resulting policies. In that case, one would expect another round of legislation which would further reform the process or impose substantive regulations where there presently is free determination by management and directors.

198. 15 U.S.C. $\S 80 a-15$ (c) (1970), formerly ch. 868 , tit. I, § 15, 54 Stat. 812 (1940). The Senate report states that this provision is "designed to assist directors in discharging their responsibilities," and that through receipt of such information "the attention of the direetors will be fixed on their responsibilities." SENATE REPORT 6.

199. 15 U.S.C. $\$ 80 a-15($ c), 31 (a) (1970), formerly ch. 686 , tit. I, $\$ 15,31$ (a), 54 Stat. 812,838 (1940).

200. Senate Report 39.

201. A plaintiff's counsel in numerous stoekholder actions, including Moses v. Burgin, discusses his ideas about future litigation in The Bómb Thrower, supra note 8, at 63-64. 
. 